\title{
Impenhorabilidade de salários: o STJ e a alteração legislativa
}

\author{
Claudia de Oliveira Fonseca ${ }^{1}$ \\ Luma Motta Fernandes²
}

Resumo: O presente estudo repousa sobre o instituto da impenhorabilidade de salários. Enquanto o CPC de 1973 tratava o salário como absolutamente impenhorável, o CPC de 2015 estabeleceu apenas que o salário é impenhorável, retirando o verbete "absolutamente". Assim, o entendimento que vem emanando da doutrina e também da jurisprudência é pela possibilidade de penhora, tendo como limite a garantia de uma existência digna ao devedor e seus dependentes. A pesquisa busca investigar como esse tema tem sido compreendido pelos estudiosos da matéria e qual a interpretação que o Superior Tribunal de Justiça (STJ) vem atribuindo no caso concreto. O presente estudo teve por base a análise documental, análise jurisprudencial e revisão bibliográfica utilizando, principalmente, as obras de Marcelo Abelha, Misael Montenegro Júnior e Marcus Vinicius Rios Gonçalves, dentre outros. Com a pesquisa foi possível verificar como o STJ foi construindo o seu entendimento jurisprudencial mesmo ainda sob a égide do CPC de 1973 e, agora mesmo diante de certa ameaça de retrocesso, a pesquisa sinaliza que não é crível que a Corte modifique o seu entendimento, violando toda essa construção jurisprudencial experimentada ao longo dos anos.

Palavras-chave: Dignidade humana. Impenhorabilidade. Responsabilidade patrimonial.

\section{Impossibility of wage garnishment: the STJ and the legislative change}

\begin{abstract}
The present research rests on the institute of wage immobilization. While the CPC of 1973 treated the salary as absolutely unreliable, the CPC of 2015 established that the salary is unreliable and removed the entry "absolutely". Thus, the understanding that emanates from the doctrine and also from the jurisprudence is due to the possibility of attachment, having as limit the guarantee of dignified evidence for debtors and their family. A research seeks to investigate how this topic was understood by scholars of subjects and what is the interpretation that the STJ (Superior Court of Justice) has given in the specific case. The present study was based on documentary analysis, jurisprudential analysis and bibliographic review, mainly, such as the works of Marcelo Abelha, Misael Montenegro Júnior and Marcus Vinicius Rios Gonçalves, among others. With a research it was possible to verify how the STJ was building its jurisprudential understanding still under the CPC of 1973 and, even now facing a certain threat of retrogression, a research signals that is not possible to cut or modify its understanding, violating all this jurisprudential construction experienced over the years.
\end{abstract}

Keywords: Human dignity. Impossibility. Patrimonial liability.

\footnotetext{
${ }^{1}$ Doutoranda em Direito pela Universidade Federal da Bahia (UFBA). Mestra em Direito pela Universidade de Brasília (UnB). Professora de Direito Público na Universidade Estadual do Sudoeste da Bahia (UESB). Advogada. Correio eletrônico: claudiauesb@gmail.com.

2 Pós-graduada em Direito Processual Civil pela UNIAMÉRICA. Bacharela em Direito pela Universidade Estadual do Sudoeste da Bahia (UESB). Advogada. Correio eletrônico: lumamfernandes@gmail.com.
} 


\section{Introdução}

Vivemos em uma sociedade marcada pela celebração de contratos. A todo tempo, pelas mais diversas razões, somos motivados a contratar um novo produto ou serviço e o fazemos da maneira mais simples possível: bastam apenas alguns toques na tela do celular. Com o estabelecimento da relação contratual, as partes se obrigam a determinadas prestações que, não sendo cumpridas, faz nascer a responsabilidade e, muitas vezes, faz-se necessário recorrer ao processo, em busca da tutela jurisdicional para solucionar esse conflito de interesses.

Quando a obrigação não é cumprida de maneira espontânea pelo devedor, mesmo após o pronunciamento judicial, surge a necessidade de prática de atos processuais para substituir a vontade da parte inadimplente. Tais atos processuais são necessários para retirar do seu patrimônio, por meio da penhora, o necessário para o adimplemento da obrigação, em cumprimento ao que está previsto na legislação processual civil no que atine à responsabilidade patrimonial. É a partir desse momento que se começa a falar da penhora.

Mas nem todos os bens do devedor podem ser objeto dessa constrição judicial: o código de processo civil traz um rol de bens que não podem ser penhorados: fruto de uma opção legislativa, para cumprir o propósito de resguardar a dignidade humana e proteger o patrimônio do devedor. Dentre essas hipóteses contempladas no CPC, analisaremos a impenhorabilidade de salários, com o propósito de verificar o entendimento doutrinário e jurisprudencial sobre o tema.

A pesquisa buscou investigar como tem sido o tratamento da doutrina e jurisprudência sobre a questão da impenhorabilidade de salários, face ao princípio constitucional da dignidade da pessoa humana. Para tanto, o estudo se pautou em análise documental, análise jurisprudencial e revisão bibliográfica.

O presente estudo está estruturado da seguinte forma: após essa introdução, apresentamos uma breve análise sobre o inadimplemento da obrigação e o caminho para a penhora de bens do devedor, com o propósito de satisfazer o credor. No tópico seguinte, trataremos da impenhorabilidade de salários e, em seguida, analisaremos a evolução do entendimento jurisprudencial do Superior Tribunal de Justiça (STJ) sobre o tema; na sequência, será feita uma breve referência ao Projeto de Lei 5.320 de 2019 e o seu risco de retrocesso. E, finalmente, serão apresentadas as considerações finais sobre a temática em estudo e as referências utilizadas. 


\section{Entre o inadimplemento da obrigação e a penhora de bens}

$\mathrm{Na}$ sociedade contemporânea tornou-se indispensável a aquisição de numerosos produtos e serviços, com a consequente necessidade de celebração de contratos. Com o estabelecimento do vínculo contratual, as partes se comprometem a entregar a prestação combinada no prazo convencionado. Se esse não for o comportamento adotado por qualquer dos contratantes, acarretando o descumprimento da obrigação, surge aí a responsabilidade. É assim que nos ensina Marcus Vinícius Rios Gonçalves:

A obrigação e a responsabilidade surgem em momentos distintos. A primeira, quando o débito é contraído (por exemplo, quando o devedor assina o contrato, comprometendo-se a realizar determinada prestação). Se houver o adimplemento, não surgirá a responsabilidade, isto é, não haverá possibilidade de invadir a esfera patrimonial do devedor. Só em caso de inadimplemento a responsabilidade se manifestará. Em regra, o responsável é o próprio devedor (GONÇALVES, 2017, p. 943).

Quando o direito de qualquer das partes dessa relação contratual não for respeitado, surge a necessidade de busca da tutela jurisdicional. É exatamente o que ocorre quando o titular de um direito material (o detentor do crédito) entende que o seu direito foi violado por outrem (o devedor). A busca pela intervenção estatal para a solução dos conflitos de interesse vai ganhando maior dimensão à medida que a autotutela é admitida em pouquíssimas situações:

\footnotetext{
Historicamente, o direito processual veio a ganhar importância em razão do reconhecimento da necessidade de intervenção estatal para a solução de conflitos de interesses ocorridos no mundo fenomênico, na medida em que o direito atual tolera pouquíssimas hipóteses de autotutela (ALVIM et al, 2019, p. 73).
}

Nesse caso, sempre que houver violação ao direito, a parte prejudicada tem a possibilidade de buscar a proteção estatal para obter a satisfação da sua pretensão. É exatamente por isso que se afirma ser o processo "o instrumento da jurisdição, o meio de que se vale o juiz para aplicar a lei ao caso concreto. Não é um fim em si, já que ninguém deseja a instauração do processo por si só, mas meio de conseguir determinado resultado: a prestação jurisdicional" (GONÇALVES, 2017, pp. 61-62).

Instrumento importante para promoção da harmonia social, o processo civil vem passando por diversas transformações, com o propósito de atender às necessidades das sociedades contemporâneas. Nos dias atuais, uma das maiores preocupações do processo civil contemporâneo é a sua efetividade: apresentar às partes envolvidas no conflito de interesses uma solução para o caso concreto. 
Entretanto, após o pronunciamento judicial, nem sempre a parte vencida cumpre, de maneira voluntária, o comando exarado na decisão. Muitas vezes faz-se necessário que a parte busque a intervenção do Poder Judiciário, por meio dos atos de constrição judicial, para a efetivação da decisão proferida. É com o ato de penhora que será possível a apreensão de bens do devedor em montante suficiente para o cumprimento da obrigação.

O ordenamento jurídico brasileiro adotou a regra da responsabilidade patrimonial. $O$ CPC, vigente, estabelece no seu artigo 789 que "o devedor responde com todos os seus bens presentes e futuros para o cumprimento de suas obrigações, salvo as restrições estabelecidas em lei”. Assim, por força desse dispositivo, o devedor é o responsável primário ${ }^{3}$ e serão os seus bens que responderão pelo adimplemento de suas obrigações, tanto "os que existiam no momento em que a obrigação foi contraída e os que não existiam ainda, e só vieram a ser adquiridos posteriormente, sejam eles corpóreos ou incorpóreos, desde que tenham valor econômico" (GONÇALVES, 2017, p. 944).

É por meio do instituto da responsabilidade patrimonial que o devedor principal ou aquele apontado, pela lei ou pelo contrato, como responsável pelo cumprimento da obrigação assume que, "caso ocorra o inadimplemento, seu patrimônio estará sujeito à atuação estatal, que poderá retirar dali o valor necessário para pagamento do que for devido" (ABELHA, 2016, p. 1.049).

Essa retirada de valores do patrimônio do devedor para cumprimento da obrigação tem início com a penhora. A penhora é o "primeiro ato por meio do qual o Estado põe em prática o processo de expropriação executiva", afirma Humberto Theodoro Júnior (2016, p. 439). E o mesmo autor acrescenta que a penhora tem a função de individualizar o bem ou os bens, sobre os quais recairão a constrição judicial.

Também nesse sentido, o entendimento de Misael Montenegro Filho, que define a penhora como um ato agressivo, porém necessário à efetividade do processo judicial quando a decisão não for cumprida de maneira voluntária:

Tem por objetivo efetuar a apreensão de bens do devedor e/ou do responsável, com vista a permitir a posterior satisfação do credor. (...) Inegavelmente agressiva em decorrência dos efeitos que produz, é necessária para que se alcance o objetivo

\footnotetext{
${ }^{3}$ Quanto à possibilidade de o pagamento da dívida atingir bens de terceiros (responsabilidade secundária), Misael Montenegro Filho leciona: "A sujeição de bens pertencentes a terceiros pode aparentar ser ilegal na medida em que permite o sacrifício de bens de pessoas que não participaram da ação de conhecimento (quanto o título executivo for judicial), e que por essa razão não poderiam ser atingidos pelos efeitos da coisa julgada, respeitando-se os limites subjetivos da res judicata. Essa conclusão é equivocada pelo fato de o nosso sistema processual distinguir o débito (Schuld) da responsabilidade (Haftung), permitindo que a execução atinja bens pertencentes a responsáveis que não sejam o próprio devedor, que se relacionam com este por questões societárias, matrimoniais ou jurídicas de modo geral” (MONTENEGRO FILHO, p. 932).
} 
primordial da execução, qual seja: a plena satisfação do credor” (MONTENEGRO FILHO, 2016, p. 996-997).

Entretanto, a própria legislação traz exceções à possibilidade de apreensão judicial de bens, em cumprimento ao princípio da menor onerosidade para o devedor, com o propósito de evitar que a responsabilidade patrimonial e os consequentes atos executórios sejam responsáveis pela sua ruína financeira - são as hipóteses de impenhorabilidade (MONTENEGRO FILHO, 2016, pp. 928-929).

A opção legislativa para que sobre determinados bens não recaiam atos de expropriação judicial é uma escolha política do legislador, teoricamente, com a finalidade de proteger um patrimônio mínimo do devedor, que seja suficiente para lhe conferir uma sobrevivência digna. Nesse sentido, afirma Marcelo Abelha:

\begin{abstract}
O motivo de o legislador livrar determinados bens do executado da incidência da responsabilidade patrimonial é de origem política, visando a contemplar valores relacionados à ética, humanitarismo, etc., tudo com vistas a atender ao postulado máximo de proteção à dignidade do executado. Assim, o art. 833 do CPC, arrola os denominados 'bens impenhoráveis', em que se leem hipóteses nas quais o legislador anteviu que naquelas situações a proteção da dignidade do executado está in re ipsa (ABELHA, 2016, p. 1057).
\end{abstract}

Demonstrando certa preocupação com esse ato de liberação de alguns bens arcarem com a responsabilidade, o mesmo autor ainda acrescenta que as hipóteses de impenhorabilidade não podem ser analisadas em descompasso com a realidade atual, de modo a permitir que o devedor as utilize para se esquivar de seu compromisso e de sua responsabilidade.

Regra geral é que a penhora deve recair sobre os bens negociáveis, isto é, sobre os bens que podem ser objeto de alienação, como determina o artigo 832 do CPC: "não estão sujeitos à execução os bens que a lei considera impenhoráveis ou inalienáveis”. Entretanto, apesar desse regramento, o CPC atual traz uma extensa lista de bens que, apesar de se tratar de bens alienáveis, não podem ser objeto de penhora - são os bens impenhoráveis.

No extenso rol dos bens impenhoráveis, o legislador fez constar: os bens inalienáveis, móveis e utilidades domésticas que guarnecem a residência do executado; os vestuários, os pertences de uso pessoal do executado; os salários, proventos de aposentadoria e demais rendimentos; os livros, máquinas e bens utilizados no exercício da profissão, entre outros.

No presente estudo, interessa-nos a impenhorabilidade de salários: instituto que já era previsto no CPC de 1973 e que foi mantido no CPC de 2015, nos termos que se verá a seguir. 


\section{Impenhorabilidade de salários}

No que diz respeito à impenhorabilidade de salários, o Código de Processo Civil de 1973 (CPC de 73) estabelecia em seu artigo 649, inciso IV ${ }^{4}$, que o salário (entre outras formas de rendimentos) era absolutamente impenhorável.

A explicação para a impenhorabilidade prevista no dispositivo legal acima mencionado era fundamentada na natureza alimentar dessas verbas. Nesse pensar, a possibilidade de penhora e uma consequente expropriação causariam prejuízos aos direitos mínimos da dignidade do devedor, uma vez que, inevitavelmente, interferiria na sua manutenção e de sua família no que diz respeito às necessidades básicas de habitação, alimentação, transporte, vestuário, educação, entre outras.

Assim, prevalecia, na doutrina e na jurisprudência, o entendimento que o salário, soldo ou remuneração eram impenhoráveis, consoante a determinação do art. 649, IV, do CPC de 73 e essa norma somente poderia ser excepcionada na hipótese de penhora para pagamento de prestação alimentícia. Nesse contexto, a orientação adotada era, exclusivamente, a preservação das condições de dignidade do devedor e seus dependentes, sem maior preocupação com a justiça da decisão e com o direito do credor à existência digna.

Durante a sua vigência, o CPC de 73 passou por algumas alterações. Dentre essas alterações, importa registrar aqui a modificação trazida com o advento da Lei 11.382/2006, quando a matéria da impenhorabilidade sofreu modificações: foi acrescentado um dispositivo que estabelecia a impenhorabilidade de valores depositados em caderneta de poupança até o limite de quarenta salários mínimos.

Essa lei 11.382/2006 foi resultado da aprovação do Projeto de Lei $4.497^{5}$ de 2004, que, além de outros regramentos, pretendia alterar a norma da impenhorabilidade para considerar “penhorável até quarenta por cento do total recebido mensalmente acima de vinte salários mínimos, calculados após efetuados os descontos de imposto de renda retido na fonte, contribuição previdenciária oficial e outros descontos compulsórios". Ao final do processo legislativo, infelizmente, esse dispositivo foi vetado pelo Presidente da República.

Portanto, apesar da tentativa do legislador para alterar o regramento da impenhorabilidade absoluta de salários, o veto presidencial ao dispositivo não permitiu a

\footnotetext{
${ }^{4}$ Art. 649 do CPC de 1973. São absolutamente impenhoráveis: IV - os vencimentos, subsídios, soldos, salários, remunerações, proventos de aposentadoria, pensões, pecúlios e montepios; as quantias recebidas por liberalidade de terceiro e destinadas ao sustento do devedor e sua família, os ganhos de trabalhador autônomo e os honorários de profissional liberal, observado o disposto no \3o deste artigo (Redação dada pela Lei no 11.382, de 2006). (...) \20 O disposto no inciso IV do caput deste artigo não se aplica no caso de penhora para pagamento de prestação alimentícia. (Incluído pela Lei no 11.382 , de 2006). (grifamos).

5 Conferir em: https://www.camara.leg.br/proposicoesWeb/fichadetramitacao?idProposicao=270517. Acesso em 20 de maio de 2020 .
} 
alteração legislativa. Assim, continuavam assegurados ao devedor que quisesse se esquivar do cumprimento de suas obrigações, não somente a integralidade dos seus rendimentos, mas também o direito à inadimplência.

Com um dispositivo muito semelhante ao do CPC de 73, o Código de Processo Civil de 2015 também trata da impenhorabilidade de rendimentos. A nova legislação retirou o verbete "absolutamente" e, em seu artigo $833, \mathrm{IV}^{6}$, prevê que tanto o salário, quanto as outras formas de rendimentos, em regra, são impenhoráveis.

Segundo Daniel Assumpção Amorim Neves, a impenhorabilidade absoluta dos salários é medida injusta naquelas situações, claramente demonstráveis, que um percentual de constrição não causará prejuízo ao devedor no que tange à sua existência em condições de dignidade. E acrescenta o mesmo autor:

\begin{abstract}
Sempre critiquei de forma severa a impenhorabilidade de salários consagrada no art. 649, IV, do CPC/1973, que contrariava a realidade da maioria dos países civilizados, que, além da necessária preocupação com a sobrevivência digna do devedor, não se esquecem que salários de alto valor podem ser parcialmente penhorados sem sacrifício de sua subsistência digna. A impenhorabilidade absoluta dos salários, portanto, diante de situações em que um percentual de constrição não afetará a sobrevivência digna do devedor, era medida injusta e derivada de interpretação equivocada do princípio do patrimônio mínimo (NEVES, 2018, p. 1141).
\end{abstract}

$\mathrm{O}$ art. $833, \sqrt{\int} 2^{\circ}$, do $\mathrm{CPC}$ vigente, determina que não se aplica a impenhorabilidade às importâncias excedentes a 50 salários mínimos mensais, bem como ao pagamento das prestações alimentícias, independentemente de sua origem. Também nesse sentido e tendo em vista o seu caráter alimentar, é importante mencionar que o Superior Tribunal de Justiça vem se manifestando pela aplicação dessa mesma regra à cobrança dos honorários advocatícios ${ }^{7}$.

Entretanto, é uma questão intrigante essa previsão da penhorabilidade da verba salarial excedente aos 50 salários mínimos. Em um país como o Brasil, marcado por uma desigualdade salarial gritante, poucos trabalhadores recebem uma remuneração nesse patamar. Portanto, por mais que se acredite no avanço trazido pela legislação, não é crível que muitos devedores serão

\footnotetext{
${ }^{6}$ Código de Processo Civil de 2015 (CPC/2015) - Art. 833. São impenhoráveis: (...) IV - os vencimentos, os subsídios, os soldos, os salários, as remunerações, os proventos de aposentadoria, as pensões, os pecúlios e os montepios, bem como as quantias recebidas por liberalidade de terceiro e destinadas ao sustento do devedor e de sua família, os ganhos de trabalhador autônomo e os honorários de profissional liberal, ressalvado o $₫ 2^{\circ}$.

7 Agravo Interno no Agravo em Recurso Especial. Processual Civil. Execução. Honorários advocatícios. Caráter alimentar. Proventos. Penhora. Possibilidade. Art. 833, 』 2 $2^{\circ}$, do CPC/2015. Percentual. Redução. Reexame do contexto fático-probatório. Súmula $n^{\circ} 7 /$ STJ. 1. Recurso especial interposto contra acórdão publicado na vigência do Código de Processo Civil de 2015 (Enunciados Administrativos nº 2 e 3/STJ). 2. Os honorários advocatícios possuem natureza alimentar, admitindo-se a penhora sobre percentual do salário para a satisfação do direito do credor. Precedentes. (...) AgInt no AREsp 1473266 / SP. Relator Ministro Ricardo Villas Bôas Cueva. Terceira Turma; julgado em 10/12/2019; DJe 13/12/2019.
} 
alcançados pela penhora de parte de seu salário, uma vez que pouquíssimos recebem uma quantia tão vultosa como fruto do seu labor.

\section{A evolução da jurisprudência do STJ: entre o CPC de 1973 e o CPC de 2015}

O certo é que ainda há muita discussão em torno do novo regramento do CPC de 2015 no que diz respeito à impenhorabilidade de salários. O atual código de processo civil trouxe modificação em comparação ao regramento contido no artigo 649 do código de processo civil de 1973, possibilitando, entre outras hipóteses, mesmo quando não se tratar de dívida de caráter alimentar, a penhora de salário no valor que exceder os 50 salários mínimos.

É verdade que a Constituição de 1988, ao estabelecer a dignidade da pessoa humana como fundamento da República Federativa do Brasil, possibilitou um novo olhar sobre o instituto da penhora: parece que o entendimento, atento ao princípio da dignidade humana, levou a uma considerável preocupação com a preservação do patrimônio, principalmente pelo fato de ser ele o garantidor das condições de existência com dignidade.

É nesse sentido a afirmação de Antônio Cláudio da Costa Machado (2007, p. 843): "registre-se, ainda, que o fundamento político da norma se vincula à ideia reconhecida universalmente de que a lei deve proteger aquilo que corresponda às necessidades básicas de sustento do ser humano (dignidade da pessoa humana - CF, art. $1^{\circ}$, III) ".

Assim, olhando por um dos ângulos, o ordenamento jurídico parecia estar preocupado com a garantia de uma existência digna e, para tanto, preocupou-se com a preservação patrimonial, uma vez que seria esse mesmo patrimônio o garantidor de uma vida em condições de dignidade. Nesse pensar, proteger a dignidade humana consistia, em certa medida, na proteção do patrimônio do devedor, em montante suficiente para lhe garantir a fruição dos direitos essenciais que sinalizam uma existência digna: moradia, saúde, educação, lazer etc.

Entretanto, parece que esse regramento legal não se mostrou capaz de proteger a dignidade humana de todos, indistintamente, pois ao blindar o patrimônio do devedor em detrimento do cumprimento de suas obrigações, não garantia o adimplemento das obrigações, deixando o credor à própria sorte. Assim, olhando desse ângulo, o que se pode perceber é que o ordenamento jurídico, apesar de estar se pautando pela preservação da existência digna de uma das partes da relação processual (o devedor), deixava em total desamparo o credor e a sua existência em condições de dignidade.

Fazendo referência ao CPC de 1973, que tratava o salário como absolutamente impenhorável, não possibilitando que parte dessa verba pudesse ser utilizada para o adimplemento das obrigações do devedor, Sérgio Cruz Arenhart (2008) afirma não ser razoável 
equiparar os diversos níveis (valores) de remuneração em um país como o Brasil, com tanta desigualdade salarial. Quando se trata de uma remuneração no valor de um salário mínimo, defende o autor, é evidente que todo o rendimento tem caráter alimentar. Entretanto, esse entendimento não pode e não deve ser aplicado aos rendimentos vultosos. De fato, existe um patamar da remuneração que deve ser protegido pela legislação, com o propósito de resguardar o princípio da dignidade humana, mas, ultrapassado esse patamar, não faz nenhum sentido atribuir o caráter alimentar à totalidade da verba remuneratória, defende o autor.

É importante mencionar que o Superior Tribunal de Justiça (STJ), mesmo durante a vigência do CPC de 1973, já vinha se manifestando, por meio de seus órgãos fracionários, pela possibilidade de penhora de parte da verba salarial, não obstante o fato de a impenhorabilidade absoluta de salários ser norma expressa, prevista no artigo 649, IV do CPC revogado.

Não se tratava de entendimento consolidado do tribunal, mas havia entendimento divergente em seus órgãos fracionários. Assim, enquanto Turmas da Primeira Seção ${ }^{8}$ entendiam que o salário era impenhorável, admitindo somente a exceção prevista no próprio código de processo civil vigente à época - a hipótese de débito alimentar - as Turmas da Segunda Seção apresentavam um entendimento diverso: seria possível a penhora, tanto na hipótese de empréstimo consignado, quanto na hipótese que o rendimento do devedor fosse capaz de suportar a penhora sem causar danos à sua própria manutenção e de sua família. Dessa forma, seria possível assegurar, a um só tempo, a dignidade das duas partes envolvidas na relação processual:

\begin{abstract}
A regra geral da impenhorabilidade, mediante desconto de conta bancária, de vencimentos, subsídios, soldos, salários, remunerações e proventos de aposentadoria, constante do art. 649, IV, do CPC, incidente na generalidade dos casos, deve ser excepcionada, no caso concreto, diante das condições fáticas bem firmadas por sentença e Acórdão na origem (Súmula 7/STJ), tendo em vista a recalcitrância patente do devedor em satisfazer o crédito, bem como o fato de o valor descontado ser módico, $10 \%$ sobre os vencimentos, e de não afetar a dignidade do devedor, quanto ao sustento próprio e de sua família. Precedentes. (REsp 1285970/SP, Rel. Ministro Sidnei Beneti, Terceira Turma, julgado em 27/05/2014, DJe 08/09/2014).
\end{abstract}

Diversas outras decisões do STJ nesse mesmo sentido ${ }^{9}$ podem ser encontradas no repositório jurisprudencial do tribunal, relativizando a regra prevista no artigo 649, IV, do CPC de 1973, ainda sob a sua vigência, ao permitir a penhora de parcela dos rendimentos do devedor. Com esse entendimento, o STJ possibilitava, a um só tempo, preservar o padrão de vida do

\footnotetext{
8 Nesse sentido: AgInt no AREsp 1116479/RJ, Rel. Ministro Sérgio Kukina, Primeira Turma, julgado em 24/10/2017, DJe 10/11/2017; AgRg no AREsp 585.251/RO, Rel. Ministro Benedito Gonçalves, Primeira Turma, julgado em 24/02/2015, DJe 04/03/2015; REsp 1.721.084, Rel. Ministro Herman Benjamin, Segunda Turma, julgado em 17/04/2018.

${ }^{9}$ Nesse sentido: AgRg no REsp 1473848/MS, Rel. Ministro João Otávio de Noronha, Terceira Turma, julgado em 22/09/2015, DJe 25/09/2015; REsp 1326394/SP, Rel. Ministra Nancy Andrighi, Terceira Turma, julgado em 12/03/2013, DJe 18/03/2013.
} 
devedor e sua família, mas também garantir à outra parte dessa relação obrigacional a satisfação do seu crédito de natureza não alimentar. Esse entendimento era pautado na ideia de observância do princípio da igualdade, da razoabilidade e da efetividade da tutela jurisdicional, entre outros.

A fundamentação para decisões que excepcionavam o próprio dispositivo legal era o fato de que se, por um lado, a remuneração servia para manter a subsistência e o padrão de vida do devedor e de sua família, por outro, é o princípio da boa-fé que deve nortear a conduta das partes na relação processual. Nesse sentido, afirma o Ministro Benedito Gonçalves, em seu julgado: "não se deve permitir que a execução reduza o executado a situação indigna; no entanto, não se autoriza que o executado abuse desse princípio, manejando-o para indevidamente impedir a atuação executiva de um direito ${ }^{10}$ ”. E acrescenta:

Para além do dever de portar-se processualmente de acordo com os preceitos da boafé, as partes têm direito ao tratamento processual isonômico, o que se revela na execução civil como o direito a receber tratamento jurisdicional que saiba equilibrar, de um lado, o direito do credor à satisfação do crédito executado e, de outro, o direito do devedor a responder pelo débito com a preservação de sua dignidade. (Emb. Div. em REsp 1.582.475/MG. Rel. Min. Benedito Gonçalves. Corte Especial, julgado em $03 / 10 / 2018)$

Com esse entendimento, fica demonstrado, portanto, que a regra de impenhorabilidade deve ser interpretada de modo a preservar uma existência em condições dignas para o devedor e seus dependentes, mas sem descuidar do direito do credor ao acesso à justiça e ao devido processo legal.

Ainda no que tange à impenhorabilidade salarial, é importante mencionar que o STJ já vinha manifestando o seu entendimento no sentido de que a impenhorabilidade abrangeria somente a última remuneração, não protegendo as eventuais sobras salariais que permanecessem na conta do devedor:

A Segunda Seção pacificou o entendimento de que a remuneração protegida pela regra da impenhorabilidade é a última percebida - a do último mês vencido - e, mesmo assim, sem poder ultrapassar o teto constitucional referente à remuneração de Ministro do Supremo Tribunal Federal. Após esse período, eventuais sobras perdem tal proteção" (EREsp 1330567/RS, Rel. Ministro Luís Felipe Salomão, Segunda Seção, julgado em 10/12/2014, DJe 19/12/2014).

Assim, com o propósito de solucionar esse impasse e trazendo uma aplicação mais harmônica do princípio da dignidade humana, em seu aspecto bilateral, o legislador infraconstitucional alterou o regramento dessa matéria, estabelecendo no CPC de 2015 a possibilidade de penhora de parte do salário, quando esse ultrapassar o montante de 50 salários

${ }^{10}$ Embargos de Divergência em Recurso Especial 1.582.475/MG. Rel. Min. Benedito Gonçalves. Corte Especial, julgado em 03/10/2018. 
mínimos. Portanto, a partir da vigência do CPC de 2015, tem-se de maneira expressa, na legislação vigente, a possibilidade de penhora de parte do salário do devedor, no que exceder esse limite estabelecido na lei processual.

Apesar de não atender, efetivamente, aos padrões brasileiros, uma vez que pouquíssimas pessoas recebem remuneração nesse patamar, não se pode negar que a nova legislação processual civil trouxe um avanço que, apesar de muito tímido, não pode ser desconsiderado.

Assim, desde que o CPC de 2015 entrou em vigência, o Superior Tribunal de Justiça (STJ) vem decidindo, em regra, nos termos previstos na nova legislação, atentando-se, contudo, para possíveis particularidades do caso concreto, sempre preservando um percentual capaz de assegurar a dignidade do devedor e de sua família. É o que se pode ver no seguinte trecho de um julgado de 2019:

\begin{abstract}
A regra geral da impenhorabilidade dos vencimentos, dos subsídios, dos soldos, dos salários, das remunerações, dos proventos de aposentadoria, das pensões (...) poderá ser excepcionada, nos termos do art. $833, \mathrm{IV}, \mathrm{c} / \mathrm{c} \mathrm{o} \$ 2^{\circ}$ do $\mathrm{CPC} / 2015$, quando se voltar: I) para o pagamento de prestação alimentícia, de qualquer origem, independentemente do valor da verba remuneratória recebida; e II) para o pagamento de qualquer outra dívida não alimentar, quando os valores recebidos pelo executado forem superiores a 50 salários mínimos mensais, ressalvadas eventuais particularidades do caso concreto. Em qualquer circunstância, deverá ser preservado percentual capaz de dar guarida à dignidade do devedor e de sua família" (REsp 1.407.062/MG. Rel. Ministro Luís Felipe Salomão, Quarta Turma, jul. 26/02/2019).
\end{abstract}

Recentemente, agora no mês de junho de 2020, o STJ proferiu julgamento nessa mesma linha de entendimento. O julgado trata de uma ação de despejo por falta de pagamento cumulada com cobrança, ajuizada em desfavor de fiadores de contrato de locação. O entendimento proferido no julgamento foi que "em situações excepcionais, admite-se a relativização da regra de impenhorabilidade das verbas salariais prevista no art. 833, IV, do CPC/2015, a fim de alcançar parte da remuneração do devedor para a satisfação do crédito não alimentar, preservando-se o suficiente para garantir a sua subsistência digna e a de sua família"11.

Essa informação sobre o valor da remuneração mensal do devedor é essencial para a hipótese de penhorabilidade salarial. Em julgamento, cuja decisão foi proferida em maio de 2020 - hipótese de execução de título extrajudicial, consistente em contrato de mútuo com caução - a falta de informação nos autos sobre o montante da verba salarial mensal do devedor, associada ao fato de não se tratar de dívida de caráter alimentar, foi crucial para que o STJ proferisse decisão pela impenhorabilidade salarial ${ }^{12}$.

\footnotetext{
11 Agravo Interno nos Embargos de Divergência em Recurso Especial 2017/0256395-9/ MG. Relator Ministra Nancy Andrighi. Segunda Seção, julgado em 16/06/2020. DJe 18/06/2020. Disponível em: https://scon.stj.jus.br/SCON/jurisprudencia/doc.jsp. Acesso em 19 de junho de 2020.

12 Processual civil. Recurso Especial. Execução. Penhora sobre salário. Possibilidade de flexibilização da impenhorabilidade de verba remuneratória. Excepcionalidade. 1. A regra geral da impenhorabilidade dos
} 
Apesar do entendimento tranquilo da jurisprudência do STJ pela possibilidade de utilização do instituto da penhora nessas hipóteses mencionadas anteriormente, a questão é que já não se tem certeza que esse avanço veio para ficar. Está tramitando, na Câmara dos Deputados, um projeto de lei que pretende alterar a redação do artigo 833 do CPC de 2015, retomando a redação da legislação processual civil revogada, que estabelecia a impenhorabilidade absoluta dos salários. O Projeto de Lei n $\mathrm{n}^{\circ}$ 5320/19 pretende alterar o CPC vigente, tornando o salário como bem absolutamente impenhorável.

\section{O Projeto de Lei 5.320 de 2019 e o risco de retrocesso}

O Projeto de Lei foi apresentado pelo deputado Eduardo Bismarck (PDT - CE) em 01/10/2019 e pretende acrescentar o parágrafo $4^{\circ}$ ao artigo 833 do CPC de 2015 com o propósito de tornar "absolutamente impenhoráveis os vencimentos, os subsídios, os soldos, os salários, as remunerações, os proventos de aposentadoria, as pensões, os pecúlios e os montepios, o seguro de vida, a pequena propriedade rural e outros”. Com a inclusão da expressão “absolutamente", na hipótese dessa alteração ser aprovada, resgata-se a redação do CPC de 1973.

$\mathrm{Na}$ justificativa de sua proposta legislativa, o autor do projeto parte do pressuposto que a relativização da impenhorabilidade salarial foi disciplinada em virtude de uma falha no texto do atual código de processo civil. Segundo ele, a sua "proposição visa corrigir essa insegurança jurídica para que os Tribunais passem a cumprir na integralidade a garantia da absoluta impenhorabilidade dos soldos salariais" ${ }^{\prime 13}$. E conclui questionando se a mudança na redação do dispositivo que tratava dessa matéria do CPC de 1973 para a redação atual do CPC de 2015, no qual foi excluída a palavra "absolutamente", tem algum significado para o STJ, quando for provocado a interpretar essa norma jurídica.

vencimentos, dos subsídios, dos soldos, dos salários, das remunerações, dos proventos de aposentadoria, das pensões, dos pecúlios e dos montepios, bem como das quantias recebidas por liberalidade de terceiro e destinadas ao sustento do devedor e de sua família, dos ganhos de trabalhador autônomo e dos honorários de profissional liberal, poderá ser excepcionada, nos termos do art. 833, IV, c/c o $\int 2^{\circ}$ do CPC/2015, quando se voltar: I) para o pagamento de prestação alimentícia, de qualquer origem, independentemente do valor da verba remuneratória recebida; e II) para o pagamento de qualquer outra dívida não alimentar, quando os valores recebidos pelo executado forem superiores a 50 salários mínimos mensais, ressalvando-se eventuais particularidades do caso concreto. Em qualquer circunstância, deverá ser preservado percentual capaz de dar guarida à dignidade do devedor e de sua família. 2. Na hipótese, o valor originário da dívida objeto de ação de execução de título extrajudicial, consistente em contrato de mútuo com caução, corresponde a $\mathrm{R} \$ 15.232,28$ (quinze mil, duzentos e trinta e dois reais). Assim, não sendo dívida de verba alimentar, nem existindo notícia de que a verba salarial mensal que se objetiva atingir seja superior a $\mathbf{5 0}$ salários mínimos, bem como ausente qualquer notícia do acórdão recorrido de particularidade no caso, impõe-se o respeito a regra da impenhorabilidade. 3. Agravo interno não provido. (AgInt no REsp 1841539/DF, Rel. Ministro Luís Felipe Salomão, Quarta Turma, julgado em 04/05/2020, DJe 12/05/2020) (grifamos).

13 Projeto de Lei $n^{\circ} 5.320$ de 2019. Disponível em: https://www.camara.leg.br/propostas-legislativas/2222807. Acesso em 20 de dezembro de 2019. 
Em nosso entendimento, não parece razoável o retorno à mesma redação que constava na legislação processual civil revogada, marcada pela violação dos princípios da dignidade da pessoa humana, da razoabilidade, da isonomia de tratamento, entre outros. A propositura dessa alteração não deve ter sido apresentada por alguém atento à jurisprudência do STJ, que mesmo sob a égide do CPC de 1973 já vinha sinalizando a necessidade de um entendimento capaz de assegurar direitos, garantir o acesso à justiça e a igualdade de tratamento processual.

Após o advento da Constituição de 1988, que abraçou o princípio da dignidade da pessoa humana como princípio fundamental da República, o ordenamento jurídico pátrio não encontra espaço para esse retrocesso legislativo, tão prejudicial a uma das partes da relação obrigacional, que viola a isonomia e a dignidade, principalmente porque é "no valor da dignidade da pessoa humana que a ordem jurídica encontra seu próprio sentido, sendo seu ponto de partida e seu ponto de chegada, na tarefa de interpretação normativa" (PIOVESAN, 2011, p. 92).

Segundo Flávia Piovesan, a proteção à dignidade humana é um superprincípio a orientar tanto o Direito Internacional quanto o Direito Interno:

\footnotetext{
A dignidade da pessoa humana, (...) está erigida como princípio matriz da Constituição, imprimindo-lhe unidade de sentido, condicionando a interpretação das suas normas e revelando-se, ao lado dos Direitos e Garantias Fundamentais, como cânone constitucional que incorpora as exigências de justiça e dos valores éticos, conferindo suporte axiológico a todo o sistema jurídico brasileiro (PIOVESAN, 2011, p. 54).
}

Apesar da apresentação da proposta de alteração da lei, mantemos a expectativa que a mudança não seja aprovada pelas casas legislativas. Entretanto, caso aconteça a aprovação da proposta, certamente, o STJ estará atento para evitar retrocessos. Se o entendimento do Tribunal foi se consolidando, gradativamente, antes mesmo da aprovação e vigência do novo CPC, não faz sentido acreditar que toda essa construção jurisprudencial se perderá no tempo para atender a um dispositivo que ofende o princípio que traduz a essência do ordenamento jurídico brasileiro - o princípio da dignidade da pessoa humana.

\section{Considerações finais}

Como vimos, a ideia de impenhorabilidade salarial foi adotada com o propósito de preservar condições materiais para que o devedor mantivesse uma existência digna, juntamente com o seu núcleo familiar. Com esse propósito, o CPC de 73 tratava os rendimentos como absolutamente impenhoráveis, com exceção para o cumprimento da obrigação alimentar.

A modificação formal desse regramento veio com o novo código de processo civil: o CPC de 2015 inovou ao trazer a previsão expressa da possibilidade de penhora de salários, no 
que exceder 50 salários mínimos. Assim, o que parecia uma modificação sutil, apenas com a retirada do verbete "absolutamente" que constava no CPC de 73 e não consta mais na legislação atual tem se revelado de grande utilidade prática, além de estar em consonância com o entendimento que já emanava do STJ na interpretação do tema.

Ao longo desse estudo foi possível perceber a mudança no entendimento jurisprudencial do STJ quanto à questão da impenhorabilidade de salário. Mesmo ainda sob a vigência do CPC de 73, que vedava expressamente a possibilidade de penhora dos rendimentos do devedor em hipóteses outras que não fossem de dívida alimentar, os órgãos fracionários do tribunal passaram a apresentar entendimentos divergentes: enquanto Turmas da Primeira Seção entendiam que deveria prevalecer a impenhorabilidade, Tu rmas da Segunda Seção passaram a proferir decisões admitindo a penhora do salário para adimplemento de obrigações diversas da dívida alimentar, desde que o rendimento do devedor suportasse esse adimplemento, sem prejuízo à sua própria manutenção e de sua família.

Nesse trilhar, na contramão legislativa, ainda que de modo não pacífico, emanava do STJ a possibilidade de penhora, como instrumento para assegurar o direito do credor, sempre que a restrição à penhora fosse injustificada e desproporcional. Dessa forma, apenas seria justificada a impenhorabilidade daquela parte do salário/rendimentos do devedor que fosse necessária para a manutenção de sua existência e de seus dependentes em condições de dignidade. Ultrapassado esse patamar, seria perfeitamente cabível a penhora.

Nem mesmo a apresentação de uma proposta de alteração legislativa para retomar a redação do CPC revogado, deve ser suficiente para causar excesso de preocupação. Isso porque o STJ já vinha sinalizando em seu entendimento, ainda durante a vigência do CPC de 73, que a dignidade humana deveria ser preservada, mas não se permitiria o abuso desse direito, violando, injustificadamente, o direito do credor à satisfação do seu crédito, demonstrando desrespeito à sua dignidade.

\section{Referências}

ABELHA, Marcelo. Manual de Direito Processual Civil. $\sigma^{a}$ ed., rev., atual. e ampl. Rio de Janeiro: Forense, 2016.

ALVIM, Eduardo Arruda; GRANADO, Daniel Willian; FERREIRA, Eduardo Aranha. Direito Processual Civil. 6a edição. São Paulo: Saraiva Educação, 2019.

ARENHART, Sérgio Cruz. A Penhorabilidade de Imóvel de Família de Elevado Valor e de Altos Salários. Revista Páginas de Direito, Porto Alegre, ano 8, no 790, 25 de junho de 2008. Disponível em: $\quad$ https://www.paginasdedireito.com.br/index.php/artigos/64-artigos-jun-2008/6025-apenhorabilidade-de-imovel-de-familia-de-elevado-valor-e-de-altos-salarios. Acesso em 16 de maio de 2020 .

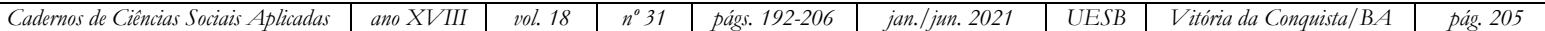


BRASIL. Código de Processo Civil, Lei no 13.105, de 16 de março de 2015. Disponível em: < http://www.planalto.gov.br/ccivil 03/ ato2015-2018/2015/lei/113105.htm> Acesso em: 09 de março de 2020.

BRASIL. Câmara dos deputados. Projeto de Lei no 5.320 de 2019. Altera o Código de Processo Civil, Lei $\mathrm{n}^{\mathrm{o}}$ 13.105, de 16 de março de 2015. Disponível em: https://www.camara.leg.br/propostas-legislativas/2222807. Acesso em 20 de dezembro de 2019.

CÂMARA, Alexandre Freitas. O Novo Processo Civil Brasileiro. São Paulo: Atlas, 2015.

GONÇALVES, Marcus Vinícius Rios. Direito Processual Civil Esquematizado. 8a edição. São Paulo: Saraiva, 2017.

MACHADO, Antônio Cláudio da Costa. Código de Processo Civil Interpretado: artigo por artigo, parágrafo por parágrafo. $6^{a}$ edição, revista e atual. Barueri, São Paulo: Manole, 2007.

MONTENEGRO FILHO, Misael. Curso de Direito Processual Civil. 12a edição, reform. e atual. São Paulo: Atlas, 2016.

NEVES, Daniel Amorim Assumpção. Manual de Direito Processual Civil - Volume único. 10². edição. Salvador: Ed. JusPodivm, 2018.

PIOVESAN, Flávia. Direitos humanos e o direito constitucional internacional. São Paulo: Saraiva, 12a edição, 2011.

THEODORO JÚNIOR, Humberto. Curso de Direito Processual Civil, volume III. 49a ed., rev., atual. e ampl. Rio de Janeiro: Forense, 2016. 